\title{
Vegetation Composition across Elevational Gradients of Pushpagiri Wildlife Sanctuary in Kodagu, Western Ghats, India
}

\author{
Vimhaseno Neikha ${ }^{1,2}$, B.C.Nagaraja ${ }^{1,3},{ }^{4}$ \\ Department of Environmental Science, Bangalore University ${ }^{l}$ \\ Email:vimhaneikha@gmail.com², nagenvi@gmail.com ${ }^{3}$ \\ Corresponding author ${ }^{4}$
}

\begin{abstract}
The present study was carried out in Pushpagiri Wildlife Sanctuary of Kodagu region in the Central Western Ghats. It aimed to understand the changes in the species composition and structure across elevational gradients. The sampling was carried out in 48 quadrats measuring $20 \times 20 \mathrm{~m}$ were laid covering an area of 1.92 ha in 16 elevational sites. A total of 824 individuals $(\geq 30 \mathrm{~cm})$ belonging to 85 species and 37 families were recorded with 36 species being endemic to the Western Ghats. Species richness varied from 8 to 22 species across the elevational sites and was highest at the mid-elevations with 22 species each at $700 \mathrm{~m}$ and $1100 \mathrm{~m}$ respectively. The forest stand density varied from 250 to $667 /$ ha and an average basal area of $38.17 \mathrm{~m}^{2}$ /ha. Pallaquium ellipticum (20.82) followed by Holigarna arnottiana (12.23) showed the highest Important Value Index. Shannon Wiener Index ranged from 1.80 to 2.86, Simpson's Diversity Index ranged from 0.81 to 0.93 and Pielou's evenness index ranged from 0.83 to 0.94 . Lauraceae contributed the most to the species richness (10 species and 113 individuals). The diversity in the species composition showed that the area harbours a rich flora. This information on species composition can be used in the preparation of management plan and in documentation of tree species. It is thus important to protect these species rich areas to conserve the biodiversity of the region.
\end{abstract}

Keywords: Conservation, Diversity, Species richness, Vegetation, Western Ghats

\section{INTRODUCTION}

Tropical forests are one of the most diverse habitats on earth and the diversity varies according to the geography, climate, habitat and disturbance [1]. Mountain regions cover about one-third of the protected areas in the world [2]. Western Ghats are a chain of mountains known for their exceptionally high level of biodiversity and endemism and were declared as one of the biodiversity hotspot's of the World [3]. Although the endemic species are not distributed uniformly along the Western Ghats [4], about $63 \%$ of the tree species in the lower and hJigher elevations evergreen forests are endemic to this region [5][6]. Topography-based analyses in mountain regions are insightful due to the topography related heterogeneity [7] relative elevation, slope convexity [8] and soil properties [9] which influence the presence of species.

Studies on floristic composition are fundamental for conservation of natural areas [10], understanding the structure of the forest [11][12]distribution patterns of the species [13] comparing the composition of species [14][15][16] biodiversity conservation [17][18] and guidance in the management of the protected areas
[19]. This study was thus carried out to study the structure and composition of the forest in Pushpagiri Wildlife Sanctuary and distribution patterns of endemic species along the elevational gradients which can be incorporated in the wildlife management plan.

\section{STUDY AREA}

Pushpagiri Wildlife Sanctuary is located in Somwarpet taluk of Kodagu district in the Central Western Ghats. It lies between $12^{\circ} 25^{\circ}$ to $12^{\circ} 40^{\prime} \mathrm{N}$ and $75^{\circ} 39^{\wedge}$ to $75^{\circ} 45^{\wedge} \mathrm{E}$ and covers an area of $102.92 \mathrm{Km}^{2}$. It was first declared as a Wildlife Sanctuary in the year 1987 but the final notification was issued in the year 1994. According to the forest type classification by Champion and Seth [20], it is composed of Southern Tropical wet evergreen forest, Southern Tropical semi-evergreen forest, Southern hilltop tropical evergreen forest and South Indian subtropical hill savanna. The sanctuary is named after the birthplace of river Lingadhaholle that originates from the Pushpagiri peak. The Sanctuary harbours a variety of flora and fauna and it also has the second highest peak in Kodagu called Pushpagiri Hill (Kumara Parvatha) at an elevation of $1712 \mathrm{~m}$ asl [21]. 


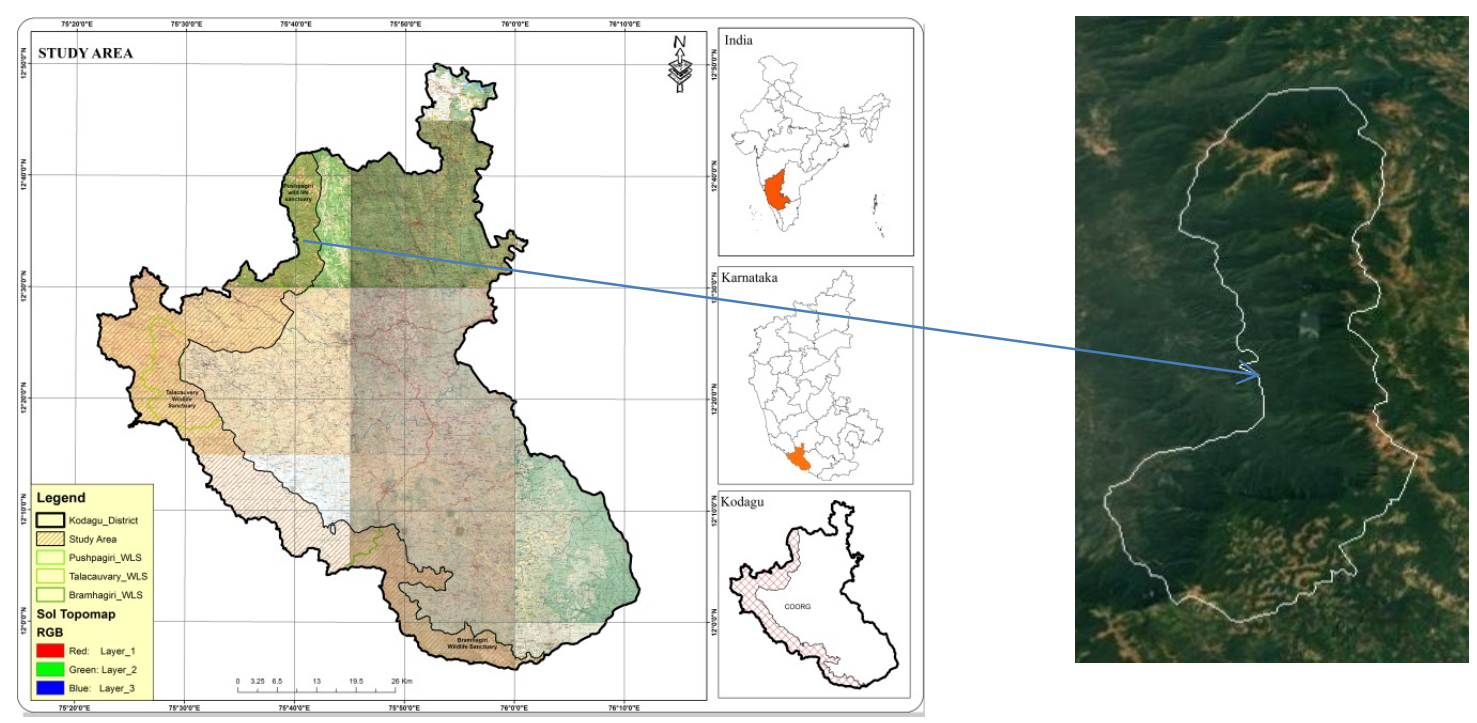

Fig 1: Map of the study area, Pushpagiri Wildlife Sanctuary in Kodagu district, India

\section{METHODOLOGY}

The vegetation composition of the study area was assessed using quadrat method following the approach of Misra [22]. The study area was divided into 16 elevational sites starting from $200 \mathrm{~m}$ till $1700 \mathrm{~m}$ at an interval of $100 \mathrm{~m}$ which covered an area of $1.92 \mathrm{ha}$. A total of 48 quadrats were laid, three quadrats measuring $20 \times 20 \mathrm{~m}$ at $20 \mathrm{~m}$ distance from each other were laid at each elevational site. The latitude, longitude and elevation data of each quadrat were obtained using a Global Positioning System (GPS) before laying down the quadrat. The trees with $\geq 30 \mathrm{~cm}$ girth at breast height $(\mathrm{GBH})$ was measured and identified with the help of experts, local floras and field guides [23][24][25] for the region. Phytosociological analysis and the floristic structure were analysed following Curtis and McIntosh [26] and Cottam and Curtis [27]. The diversity indices were analysed using the Shannon-Wiener diversity index [28], Simpson's diversity index [29] and Pielou's evenness index [30].

\section{RESULTS AND DISCUSSIONS}

\section{Species diversity}

The study on the natural forest of Pushpagiri Wildlife Sanctuary in the Western Ghats showed a wide diversity in the tree species composition. A total of $824(\geq 30 \mathrm{~cm})$ individuals belonging to 85 trees species, 64 genera and 37 families were recorded. Out of the 16 study sites, Holigarna arnottiana and
Persea macrantha were found to be common in 10 elevations and Dimocarpus longan and Myristica malabarica were found to be common in 9 elevations. None of the species was found to occur in all the elevational sites. A total of 22 species each were recorded for 700 and $1000 \mathrm{~m}$ elevations. It was then followed by 21 tree species each at 200, 300 and 1100 $\mathrm{m}$ respectively. Regression drawn between species richness and elevation showed a positive correlation $\left(\mathrm{R}^{2}=0.44\right)$ (Fig 2a). The species diversity according to the Shannon Wiener Index varied along the 16 elevational sites with values ranging between 1.80 and 2.86. The diversity index was highest at $1100 \mathrm{~m}$ with 2.86 and $1700 \mathrm{~m}$ had the lowest diversity with 1.80 . The Simpson's diversity index which takes into account the number of species present as well as the relative abundance of each species varied between 0.81 at $1700 \mathrm{~m}$ and 0.93 at 200 and $1100 \mathrm{~m}$. Pielou's evenness index (E) ranges between 0 and 1 with the value closer to 1 having more evenness in the distribution. The sites at 900 and $1100 \mathrm{~m}$ with a value of 0.94 showed a more even distribution in the tree species and the site at $700 \mathrm{~m}$ with a value of 0.83 showed the least evenness in the distribution (Table $1)$.

\section{Endemism}

A total of 36 species endemic to the Western Ghats belonging to 431 individuals and 20 families were recorded [6] (Appendix 1). The number of endemic species varied from 3 to 14 across the elevational sites. Endemic species richness was highest at $1000 \mathrm{~m}$ 
International Journal of Research in Advent Technology, Vol.7, No.2, February 2019

\author{
E-ISSN: 2321-9637 \\ Available online at www.ijrat.org
}

with 14 species and lowest at $1700 \mathrm{~m}$ with 3 species. The total number of endemic individuals was highest at $1200 \mathrm{~m}$ with 57 and lowest at $400 \mathrm{~m}$ with 12 (Fig2b). Litsea mysorensis (35) and Kingiodendron pinnatum (31) were the dominant individuals. Lauraceae was the dominant family in terms of species richness with 6 species and 76 individuals.

\section{Family composition}

A total of 37 families were recorded from the 16 elevation sites. Lauraceae with 10 tree species $(11.76 \%)$ was the most dominant family followed by Anacardiaceae with 7 tree species $(8.24 \%)$. The family that dominated the stand with the highest number of individuals was Lauraceae (113) contributing to $13.71 \%$ of the total stand density followed by Dipterocarpaceae and Oleaceae (61) with $7.40 \%$ (Fig 2c).

\section{Stand density and basal area}

The forest stand density in the sites varied from 250 to 667 /ha with a mean stand density of 429 /ha. The stand density was highest at $1200 \mathrm{~m}$ with 667 /ha followed by 567 /ha at $1300 \mathrm{~m}$ and the lowest stand density was at $1700 \mathrm{~m}$ with $250 /$ ha respectively. The basal area ranged between $5.83 \mathrm{~m}^{2} /$ ha and $110 \mathrm{~m}^{2} /$ ha with a mean basal area of $38.17 \mathrm{~m}^{2} /$ ha (Table 1$)$. The highest basal area was at $1200 \mathrm{~m}$ with $110 \mathrm{~m}^{2} / \mathrm{ha}$, it can be attributed to the presence of Pallaquium ellipticum at $1200 \mathrm{~m}$ with a girth size of $5.8 \mathrm{~m}$. Pallaquium ellipticum was predominant in this elevation with 20 individuals and contributed to 59.44 $\mathrm{m}^{2} /$ ha of the total basal area of $1200 \mathrm{~m}$.

\section{Forest stand structure}

The growth of a forest is indicated by the distribution of trees in various girth classes. The girth of the trees were divided into seven classes $(30-60 \mathrm{~cm}, 60-90 \mathrm{~cm}$, $90-120 \mathrm{~cm}, 120-150 \mathrm{~cm}, 150-180,180-210 \mathrm{~cm}$ and $>210 \mathrm{~cm}$ ). The $30-60 \mathrm{~cm}$ girth class trees comprised of $51.16 \%$ of the trees present in the forest, $22.05 \%$ in $60-90 \mathrm{~cm}, 10.48 \%$ in $90-120 \mathrm{~cm}, 6.58 \%$ in $120-150$ $\mathrm{cm}, 4.02 \%$ in $150-180 \mathrm{~cm}, 2.19 \%$ in $180-210 \mathrm{~cm}$ and the highest girth class of $>210$ comprised of $3.90 \%$. The maximum numbers of individuals were in the $30-60 \mathrm{~cm}$ and the stand structure of the forest showed a reverse $J$ shape curve (Fig 2d). The Important Value Index (IVI) which gives a measure of the dominance of a species in an area was highest for Pallaquium ellipticum (20.77) followed by Holigarna arnotianna (12.15) and Dimocarpus longan (9.70). The minimum IVI value was recorded for Cinnamomum sulphuratum (0.47)( Fig 2f)(Appendix 1).

\section{Tree Canopy}

The mature tree species were grouped into three classes based on their height, top canopy $(>25 \mathrm{~m})$, mid-canopy $(15-25 \mathrm{~m})$ and understory $(<15 \mathrm{~m})$ [31]. The results showed that $74 \%$ of the trees are understorey trees, $22 \%$ of the trees are mid-canopy trees and $3 \%$ constitute the top canopy cover. The most dominant understorey tree was Litsea floribunda, Kingiodendron pinnatum for mid-canopy and Pallaquium ellipticum for the top canopy.

The number of species (85) recorded in the study is comparable with the number of species recorded in other parts of the Western Ghats [32][33]. The diversity index $\left(\mathrm{H}^{\prime}\right)$ values of $1.80-2.86$ from this study is lower than the evergreen forests of Kodagu [34]. It is however, difficult to compare sites based on the diversity index because of the differences in the plot size and the diameter or girth considered for the study. The mean tree density of 429 /ha is greater than that as reported in the Western Ghats [35] but lower compared to studies done in other areas of the Western Ghats with $\geq 30 \mathrm{~cm}$ girth threshold [36][37]. The average basal area of $38.17 \mathrm{~m}^{2}$ /ha is higher compared to Dawkin's [38] where he estimated the average basal area for tropical lowland evergreen forest at about $36 \mathrm{~m}^{2} / \mathrm{ha}$. It is also higher than the Eastern Ghats [39] but lower than the estimates from studies done in other parts of the Western Ghats [40]. The low tree density and basal area as compared to the other studies can be due to the differences in the sampling size [41], the elevation of the study area, as altitude and slope of a place can affect the species richness and the dispersion behaviour of trees [42]. The species diversity of a place can also depend on the site representativeness, various site attributes and the extent of human interaction in the past and present [43]. The vegetation composition varied along the elevational sites with more species richness in the lower elevations with peak in the mid-altitudes and decreasing higher up the elevations. The girth size of the trees also decreased with elevation with larger girth trees present in the lower elevations and the species richness of the trees also decreased with increase in girth class. The decrease in the species richness is a general trend found in the tropical forests [44[45[46]. The stand structure of the forest which showed a reverse $\mathrm{J}$ shape is similar to the pattern found in the studies done by Pascal and Pelisser [47], Ganesh et al., [48] which indicates the undisturbed nature of the forest [49]. It can therefore be said that the sanctuary harbours a growing and a healthy population of trees. 
International Journal of Research in Advent Technology, Vol.7, No.2, February 2019

E-ISSN: 2321-9637

Available online at www.ijrat.org

Table 1: Floristic richness and diversity indices for Pushpagiri Wildlife Sanctuary, Kodagu.

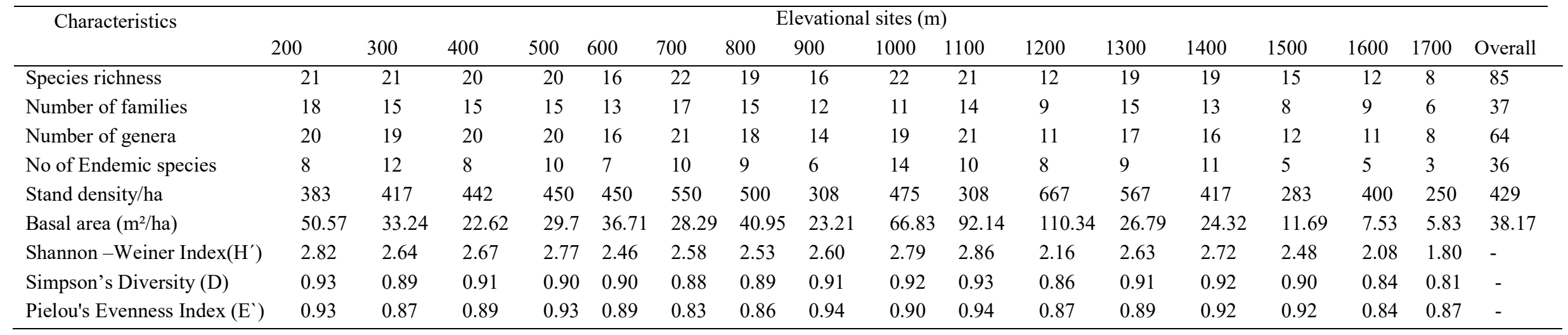
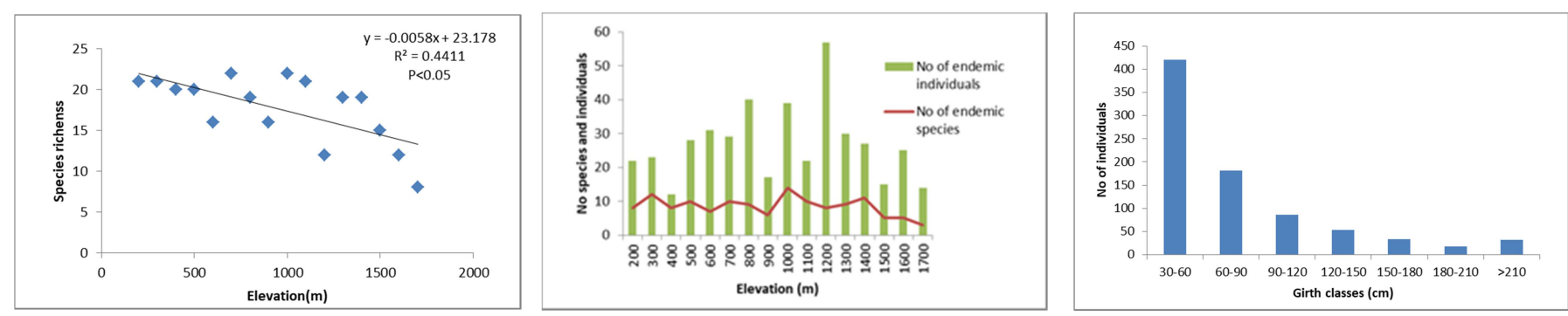

Fig 2: a) Elevational gradient of Species richness b) Elevational gradient of endemic species \& individuals c) Girth class distribution

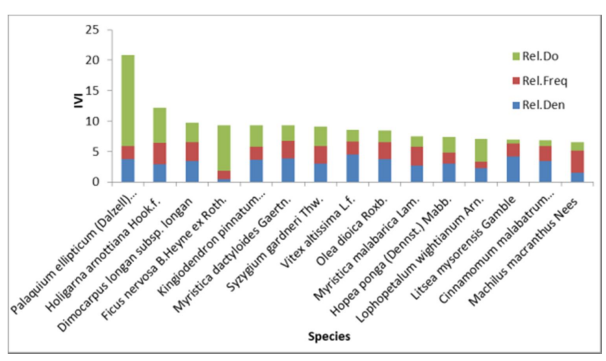

f) IVI of the top 15 species in Pushpagiri Wildlife Sanctuary, Kodagu.

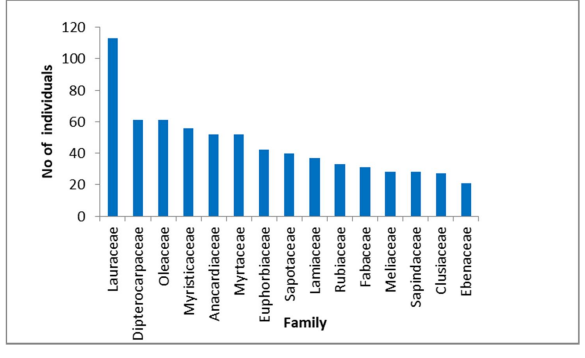

d) Top 15 Family wise distribution of the number of individuals 


\section{CONCLUSION}

The findings from this study showed that the forest structure and composition changed along the elevational gradients. The lower elevations had higher species diversity as compared to the higher elevations. The study showed the dominance of Pallaquium ellipticum along riparian areas in the lower elevations. Pushpagiri Wildlife Sanctuary harbors a diverse flora along with a high number of endemic species. Thus, continued conservation efforts and site specific management plans needs to be implemented to conserve the biodiversity of the Sanctuary.

\section{ACKNOWLEDGEMENT}

The authors are thankful to the Karnataka Forest Department for giving the permission to carry out this study and the Ministry of Tribal Affairs for funding the study under the National Fellowship for Higher Education of ST students.

\section{REFERENCES}

[1] T. C. Whitmore. "An introduction to tropical rain forests". Oxford, UK: Oxford University Press.1998.

[2] United Nations (UN). "Earth Summit. Agenda 21". The United Nations Programme of Action from Rio. United Nations, New York. Retrieved fromhttp://www.un.org/esa/dsd/agenda21/res_age nda21_00.shtml [Accessed 15 May 2018].1992.

[3] N. Myers, R. A. Mittermeier, C. G. Mittermeier, G. A. B. da Fonseca, and J. Kent. "Biodiversity hotspots for conservation priorities". Nature, 403:853-858,2000.

[4] J. P. Pascal, B. R. Ramesh, and D. De Franceschi. "Wet evergreen forest types of the Southern Western Ghats, India". Tropical Ecology. 45(2):281-292,2004.

[5] B. R. Ramesh, J. P. Pascal, and D. De Franceschi. "Distribution of endemic, arborescent evergreen species in the Western Ghats".In:Proceedings of the rare, endangered, and endemic plants of the Western Ghats. Kerala Forest Department,pages 20-29, 1991.

[6] B. R. Ramesh, and J. P. Pascal. "Atlas of endemics of the Westerns Ghats (India). Distribution of tree species in the evergreen and semi-evergreen forests". Institut Francais De Pondichery,pages 1- 403,1997.

[7] M. Bunyan, S. Bardhan, A. Singh, and S. Jose. "Effect of topography on the distribution of tropical montane forest fragments: a predictive modelling approach. Journal of Tropical Forest Science, 27(1): 30-38,2015.

[8] K. Sri-Ngernyuang, M. Kanzaki, T. Mizuno, H. Noguchi, S. Teejuntuk, C. Sungpalee, M. Hara, T. Yamakura, P. Sahunalu, P. Dhanmanonda, and S. Bunyavejchewin. "Habitat differentiation of
Lauraceae species in a tropical lower montane forest in northern Thailand". Ecological Research, 18(1):1-14,2003.

[9] T. Tange, H. Yagi, S. Sasaki, K. Niiyama, and A. R. Kassim. "Relationship between Topography and soil properties in a hill dipterocarp forest dominated by Shorea curtisii at Semangkok Forest Reserve, Peninsular Malaysia”. Journal of Tropical Forest Science, 10(3):398-409,1998.

[10] S. Singh, Z. A. Malik, and C. M. Sharma. "Tree species richness, diversity and regeneration status in different oak (Quercus spp.) dominated forests of Garhwal Himalya, India". Journal of AsiaPacific Biodiversity, 9:293-300,2016.

[11]A. H. Gentry. "Changes in plant community diversity and floristic composition on environmental and geographical gradients. Annals of the Missouri Botanical Garden,75(1):134,1988 .

[12]R. Ozcelik. "Tree species diversity of natural mixed stands in eastern Black sea and western Mediterranean region of Turkey". Journal of Environmental Biology,30:761-766,2009.

[13] A. Giriraj, M. Irfan-Ullah, M. S. R. Murthy, and C. Beierkuhnlein. "Modelling spatial and temporal forest cover change patterns (19732020): A case study from South Western Ghats (India)". Sensors,8(10):6132-6153,2008.

[14] C. M. Sharma, S. Suyal, S. Gairola, and S. K. Ghldiyal. Species richness and diversity along an altitudinal gradient in moist temperate forest of Garhwal Himalaya. Journal of American Science,5(5):119-128,2009.

[15] S. Joseph, K. Anitha, V. K. Srivastava, C. S. Reddy, A. P. Thomas, and M. S. R. Murthy. Rainfall and elevation influence the local-scale distribution of tree community in the Southern Region of Western Ghats Biodiversity Hotspot (India). International Journal of Forestry Research, 4387,2012.

[16] M. T. Naidu, and O. A. Kumar. "Tree diversity, stand structure and community composition of tropical forests in Eastern Ghats of Andhra Pradesh, India". Journal of Asia-Pacific Biodiversity, 9:328-334,2016.

[17]J. S. Singh. "The biodiversity crisis: a multifaceted review". Current Science, 82:638$647,2002$.

[18] C. Baraloto, Q. Molto, S. Rabaud, B. Hérault, R. Valencia, L. Blanc, P. V. A. Fine, and J. Thompson. "Rapid simultaneous estimation of above ground biomass and tree diversity across Neotropical forests: a comparison of field inventory methods". Biotropica, 45:288-298,2013

[19]M. N. Suratman. "Tree species diversity and forest stand structure of Pahang National Park, Malaysia”. Biodiversity Enrichment in a Diverse 
world, chapter -18. Intech, open science, open minds. 2012.

[20]H. G. Champion, and S. K Seth. "A revised survey of the forest types of India". Manager of publications, New Delhi.1968.

[21] Karnataka Forest Department. Management plan for Pushpagiri Wildlife Sanctuary (2008-09 to 2017-18. Government of Karnataka.2008.

[22] R. Misra. "Ecology Workbook". Oxford and IBH Publishing Company, Calcutta.1968.

[23] J. P. Pascal, and B. R. Ramesh. "A Field Key to the trees and lianas of the Evergreen forests of the Western Ghats". Institut Francias De Pondichery. pages 1-220,1987.

[24] K. R. Murthy, and S. N. Yoganarasimhan. "Flora of Coorg (Kodagu) Karnataka, India”. Vismat publishers. 1990.

[25] S. G. Neginhal. "Forest trees of the Western Ghats (includes Eastern Ghats and Deccan Plateau)". Published by S.G.Neginhal, pages1491.2011.

[26] J. T. Curtis, and R. P. McIntosh. "The interrelations of certain analytic and synthetic phytosociological characters". Ecology, 31(3):434- 455, 1950.

[27] G. Cottam, and J. T. Curtis. "The use of distance measures in phytosociological sampling". Ecology, 37(3):451- 460,1956.

[28] C. E. Shannon. "A mathematical theory of communication". The Bell System Technical Journal, 27 (3):379-423,1948.

[29] E. H. Simpson. "Measurement of diversity". Nature, 163:688,1949.

[30] E. C. Pielou. "Ecological diversity". Wiley, New York, 165.1975.

[31] U. M. Chandrashekara, and P. S. Ramakrishnan. Vegetation and gap dynamics of a tropical wet evergreen forest in the Western Ghats of Kerala, India. Journal of Tropical Ecology, 10(3):3 37$354,1994$.

[32] T. Ganesh, R. Ganesan, D. M. Soubadra, P. Davidar, and K. S. Bawa. "Assessment of plant biodiversity at a mid-elevation evergreen forest of Kalakad-Mundanthurai Tiger reserve, Western Ghats,India”. Current Science, 71:379-392,1996.

[33] K. Kadavul, and N. Parthasarathy. "Structure and composition of woody species in semi-evergreen forest of Kalrayan Hills, Eastern Ghats, India". Tropical Ecology, 40:247-260,1999.

[34] M. B. N. Sathish, S. Viswanath, C. G. Kushalappa, M. R. Jagadish, and K. N. Ganeshaiah. "Comparative assessment of floristic structure, diversity and regeneration status of tropical rain forests of Western Ghats of Karnataka, India". Journal of Applied and Natural Sciences, 5(1): 157-164,2013.
[35] G. Utkarsh, N. V. Joshi, and M. Gadgil. "On the patterns of tree diversity in the Western Ghats of India". Current science, 75 (6):594-603,1998.

[36] U. M. Chandrashekara, and P. S. Ramakrishnan. "Vegetation and gap dynamics of a tropical wet evergreen forest in the Western Ghats of Kerala, India". Journal of Tropical Ecology, 10 (3):337$354,1994$.

[37] N. Parthasarathy. "Tree diversity and distribution in undisturbed and human impacted sites of tropical wet evergreen forest in southern Western Ghats, India". Biodiversity Conservation, 8:1365-1381,1999.

[38]H. C. Dawkins. "The volume increment of natural tropical high forest and limitations on its improvement”. Empire Forestry Review,38:175$180,1959$.

[39] K. Kadavul, and N. Parthasarathy. "Plant biodiversity and conservation of tropical semievergreen forest in the Shervarayan hills of Eastern Ghats, India". Biodiversity and Conservation, 8(3):419-437,1999.

[40] N. Ayyapan, and N. Parthasarathy. "Biodiversity inventory of trees in a large scale permanent plot of tropical evergreen forest at Varagalaiar, Anamalais, Western Ghats, India". Biodiversity and conservation, 8 (11):1533-1554,1999.

[41] R. Jayakumar, and K. K. N. Nair. "Species diversity and tree regeneration patterns in tropical forests of the Western Ghats, India". Hindawi publishing corporation. ISRN Ecology,2013:1$14,2013$.

[42] G. Eilu, and J. Obua. "Tree condition and natural regeneration in disturbed sites of Bwindi Impenetrable Forest National Park, southwestern Uganda". Tropical Ecology,46(1):99-101,2005.

[43] N. Parthasarathy. "Changes in forest composition and structure in three sites of tropical evergreen forests around Sengaltheri, Western Ghats". Current Science, 80:389-393,2001.

[44] J. A. G. Vazquez, and T. J. Givnish. "Altitudinal gradients in tropical forest composition, structure and diversity in the Sierra de Manantlan”. Journal of Ecology, 86(6):999-1020,1998.

[45] V. Srinivas, and N. Parthasarathy. "Comparative analysis of tree diversity and dispersion in the tropical lowland evergreen forest of Agumbe,Central Western Ghats, India". Tropical biodiversity, 7(1):45-60,2000.

[46] C. S. Rana, and S. Gairola. "Forest Community Structure and Composition along an Elevational Gradient of Parshuram Kund Area in Lohit District of Arunachal Pradesh, India”. Nature and Science, 1: 44-52,2009.

[47] J. P. Pascal, and R. Pelisser. "Structure and floristic composition of a tropical evergreen forests in south west India". Journal of Tropical Ecology, 12 (2):191 - 214,1996. 
International Journal of Research in Advent Technology, Vol.7, No.2, February 2019 E-ISSN: 2321-9637

Available online at www.ijrat.org

[48] T. Ganesh, M. S. Devy, and P. Davidar. "Pollination and fruit dispersal in the wet forests of southern Western Ghats. In: Tropical ecosystems: structure, diversity and human welfare". (eds) Ganeshaiah, K.N., Umashaankar, R. and Kamaljit Bawa, Oxford and IBH publishing company Private Limited, pages 363 365,2001 .
[49] R. Kanade, M. Tadwalkar, C. Kushalappa, and A. Patwardhan. Vegetation composition and woody species diversity at Chandoli National Park, northern Western Ghats, India. 95(5):637646. 2008.

Appendix 1: Basal area and IVI of the tree species in Pushpagiri Wildlife Sanctuary, Kodagu (*Endemic to the Western Ghats)

\begin{tabular}{|c|c|c|c|c|}
\hline Sl.No & Species name & Family & $\begin{array}{c}\text { Basal area } \\
\left(\mathbf{m}^{2} / \mathbf{h a}\right)\end{array}$ & IVI \\
\hline 1 & Actinodaphne bourdillonii Gamble* & Lauraceae & 0.06 & 2.17 \\
\hline 2 & Aglaia elaeagnoidea (A. Juss.) Benth.* & Meliaceae & 0.31 & 2.38 \\
\hline 3 & Aglaia simplicifolia (Bedd.) Harms.* & Meliaceae & 0.12 & 3.43 \\
\hline 4 & Agrostistachys borneansis Becc. & Euphorbiaceae & 0.26 & 1.76 \\
\hline 5 & Antidesma menasu (Tul.) Miq. ex Muell.-Arg. & Phyllanthaceae & 0.01 & 0.51 \\
\hline 6 & Antidesma montanum Blume. & Phyllanthaceae & 0.02 & 0.53 \\
\hline 7 & Aporosa lindleyana (Wight) Baill. & Euphorbiaceae & 0.24 & 4.46 \\
\hline 8 & Archidendron bigeminum (L.)I.C.Nielsen & Mimosoideae & 0.16 & 1.85 \\
\hline 9 & Artocarpus heterophyllus Lam. & Moraceae & 0.98 & 3.05 \\
\hline 10 & Artocarpus hirsutus Lam.* & Moraceae & 0.01 & 4.07 \\
\hline 11 & Calophyllum apetalum Willd.* & Callophyllaceae & 0.51 & 3.01 \\
\hline 12 & Carallia brachiata (Lour.) Merr. & Rhizophoraceae & 0.13 & 0.81 \\
\hline 13 & Caryota urens L. & Arecaceae & 0.14 & 1.43 \\
\hline 14 & Celtis philippensis wightii (Planch.) E. Soepadmo & Cannabaceae & 0.08 & 0.81 \\
\hline 15 & Chionanthus mala-elengi (Dennst.) P.S.Green & Oleaceae & 0.25 & 4.96 \\
\hline 16 & Chukrasia tabularis A. Juss. & Meliaceae & 0.01 & 0.50 \\
\hline 17 & Cinnamomum malabatrum (Burm. f.) Pres1* & Lauraceae & 0.39 & 6.89 \\
\hline 18 & Cinnamomum sulphuratum Nees* & Lauraceae & 0.00 & 0.48 \\
\hline 19 & Cinnamomum verum J. S. Presl & Lauraceae & 0.17 & 0.91 \\
\hline 20 & Croton laccifer L. & Euphorbiaceae & 0.01 & 0.98 \\
\hline 21 & Cryptocarya wightiana Thw. & Lauraceae & 0.01 & 1.57 \\
\hline 22 & Dillenia pentagyna Roxb. & Dilleniaceae & 0.09 & 0.70 \\
\hline 23 & Dimocarpus longan subsp. longan & Sapindaceae & 1.22 & 9.78 \\
\hline 24 & Diospyros assimilis Bedd. & Ebenaceae & 0.04 & 0.59 \\
\hline 25 & Diospyros ebenum J.Koenig ex Retz. & Ebenaceae & 0.04 & 1.53 \\
\hline 26 & Diospyros paniculata Dalzell* & Ebenaceae & 0.11 & 1.86 \\
\hline 27 & Diospyros sp. & Ebenaceae & 0.27 & 3.34 \\
\hline 28 & Dipterocarpus indicus Bedd.* & Dipterocarpaceae & 0.30 & 2.92 \\
\hline 29 & Drypetes oblongifolia (Bedd.) Airy Shaw* & Putranjivaceae & 0.27 & 1.44 \\
\hline 30 & Dysoxylum malabaricum Bedd. ex C. DC.* & Meliaceae & 0.08 & 1.65 \\
\hline 31 & Erythroxylum sp. & Erythroxylaceae & 0.01 & 0.50 \\
\hline 32 & Ficus nervosa B.Heyne ex Roth. & Moraceae & 2.83 & 9.31 \\
\hline 33 & Garcinia gummi-gutta (L.) Robs.* & Clusiaceae & 0.41 & 5.38 \\
\hline 34 & Garcinia indica (Thouars) Choisy.* & Clusiaceae & 0.24 & 3.12 \\
\hline 35 & Glochidion ellipticum Wight $*$ & Euphorbiaceae & 0.14 & 3.71 \\
\hline 36 & Gordonia obtusa Wall. ex Wight \& Arn.* & Theaceae & 0.07 & 1.74 \\
\hline 37 & Grewia tiliifolia Vahl. var. tilifolia & Malvaceae & 0.38 & 1.47 \\
\hline 38 & Holigarna arnottiana Hook.f. * & Anacardiaceae & 2.21 & 12.23 \\
\hline 39 & Holigarna grahamii (Wight) Kurz* & Anacardiaceae & 0.13 & 1.53 \\
\hline 40 & Hopea canarensis Hole & Dipterocarpaceae & 1.70 & 6.37 \\
\hline 41 & Hopea parviflora Bedd.* & Dipterocarpaceae & 0.71 & 4.49 \\
\hline 42 & Hopea ponga (Dennst.) Mabb.* & Dipterocarpaceae & 1.01 & 7.44 \\
\hline 43 & Humboldtia brunonis Wall. * & Fabaceae & 0.01 & 0.50 \\
\hline 44 & Hydnocarpus pentandra (Buch.-Ham.) Oken* & Flacourtiaceae & 1.11 & 3.87 \\
\hline 45 & Ixora brachiata Roxb.* & Rubiaceae & 0.44 & 5.84 \\
\hline
\end{tabular}




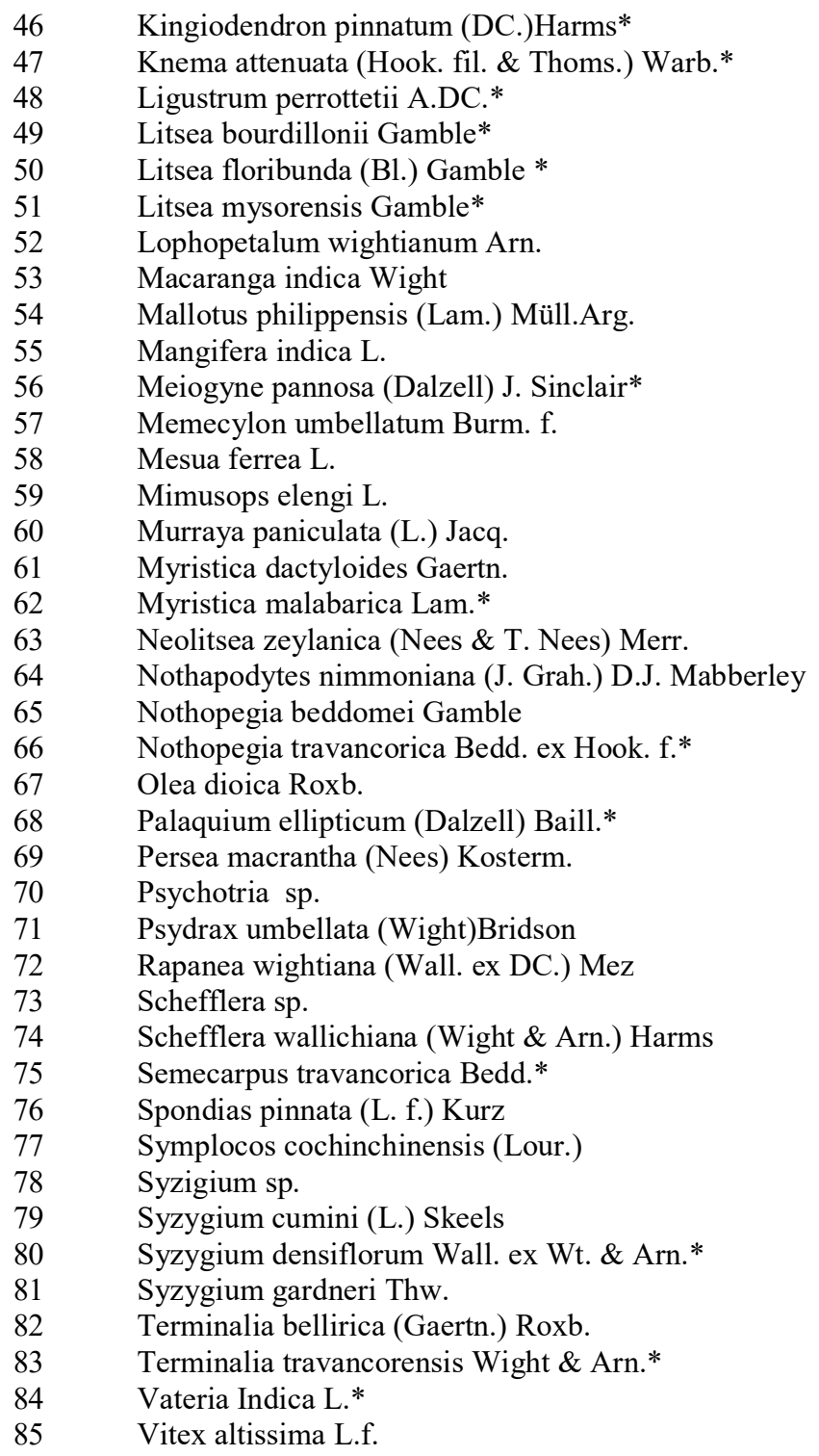

Total

$\begin{array}{lll}\text { Fabaceae } & 1.35 & 9.31 \\ \text { Myristicaceae } & 0.03 & 1.04 \\ \text { Oleaceae } & 0.08 & 1.67 \\ \text { Lauraceae } & 0.03 & 0.55 \\ \text { Lauraceae } & 0.70 & 3.63 \\ \text { Lauraceae } & 0.21 & 6.92 \\ \text { Celastraceae } & 1.40 & 7.05 \\ \text { Euphorbiaceae } & 0.28 & 4.65 \\ \text { Euphorbiaceae } & 0.31 & 2.49 \\ \text { Anacardiaceae } & 0.14 & 1.32 \\ \text { Annonaceae } & 0.27 & 2.13 \\ \text { Melastomataceae } & 0.14 & 3.14 \\ \text { Calophyllaceae } & 0.51 & 2.30 \\ \text { Sapotaceae } & 0.75 & 4.82 \\ \text { Rutaceae } & 0.01 & 0.63 \\ \text { Myristicaceae } & 0.99 & 9.30 \\ \text { Myristicaceae } & 0.64 & 7.54 \\ \text { Lauraceae } & 0.26 & 4.04 \\ \text { Stemonuraceae } & 0.28 & 3.13 \\ \text { Anacardiaceae } & 0.05 & 1.20 \\ \text { Anacardiaceae } & 0.17 & 2.00 \\ \text { Oleaceae } & 0.71 & 8.44 \\ \text { Sapotaceae } & 5.69 & 20.82 \\ \text { Lauraceae } & 0.53 & 6.50 \\ \text { Rubiaceae } & 0.01 & 0.50 \\ \text { Rubiaceae } & 0.10 & 2.28 \\ \text { Myrsinaceae } & 0.06 & 1.94 \\ \text { Araliaceae } & 0.05 & 0.96 \\ \text { Araliaceae } & 0.01 & 0.51 \\ \text { Anacardiaceae } & 0.35 & 3.08 \\ \text { Anacardiaceae } & 0.10 & 1.34 \\ \text { Symplocaceae } & 0.06 & 0.63 \\ \text { Myrtaceae } & 0.09 & 1.78 \\ \text { Myrtaceae } & 0.42 & 2.18 \\ \text { Myrtaceae } & 0.24 & 3.77 \\ \text { Myrtaceae } & 1.25 & 9.15 \\ \text { Combretaceae } & 0.44 & 2.57 \\ \text { Combretaceae } & 0.40 & 4.17 \\ \text { Dipterocarpaceae } & 0.55 & 4.07 \\ \text { Lamiaceae } & 0.76 & 8.61 \\ & & 300\end{array}$

